Plant Production Science

http:/www.journals.zu.edu.eg/journalDisplay.aspx?Journalld=1\&queryType=Master

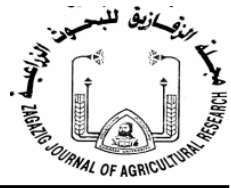

\title{
SENESCENCE OF ROSE FLOWERS 2- REGULATION AGING AND PROLONG THEIR VASE LIFE
}

\author{
Mostafa A. El-Nabarawy", E.H. El-Kafafi, H.E. Abo El-Enien and M.K. Salama \\ Agric. Bot. Dept., Fac. Agric., Al-Azhar Univ., Nasr City, Cairo, Egypt
}

Received: 18/03/2018 ; Accepted: 24/04/2018

\begin{abstract}
This study was carried out in a laboratory of Plant Physiology, Faculty of Agriculture, Al-Azhar University, Nasr city Cairo, Egypt during 2013 - 2016 A.D to comparison between Rosa hybrida L. cultivars (Anna and Gold strike cvs.) reported that Anna cv. have the shortlongevity vase life (early senescence) and Gold strike cv. which have long-longevity (late senescence). The effect of exogenous sucrose (Suc), ethanol (Eth), ethanol + sucrose (Eth+Suc), salicylic acid (SA), 5-sulfosalycilic acid (5-SSA), silver thiosulphate (STS) and benzyladenine (BA) on the longevity of vase life for two cut rose flowers (Anna and gold strike cvs.) was investigated. Some physiological and biochemical traits such as water relations (water uptake, water loss and relative fresh weight), stability membrane, electrolyte leakage, chlorophyll a,b and carotenoids, lipid peroxidation, thiobarbituric acid reactive substances (TBARS), hydrogen peroxide $\left(\mathrm{H}_{2} \mathrm{O}_{2}\right)$, peroxidase (POD), superoxide dismutase enzyme (SOD) activity and endogenous hormones i.e. indole acetic acid (IAA), cytokinin (CKs), gibberellic acid (GA3) and abscisic acid (ABA) were measured. Results reported that, the vase life evidently all treatments were better treated, 1mM SA, $6 \%$ Eth, $6 \%$ Eth $+2 \%$ Suc recorded vase life valued 7,6 and 6 days, respectively with Anna cv. compared with their control (4 days), while Gold strike cv. with same better treated recorded 12,11 and 11 days, respectively when compared with control ( 8 days). Results reported that ethanol $6 \%+2 \%$ sucrose and salicylic acid at 1 $\mathrm{mM}$ reduced lipid peroxidation and consequently prolonged membrane integrity, antioxidant enzymes (POD and SOD) activity observed was dramatically in two cultivars. While, water relations (water uptake, water loss and relative fresh weight) was better for the best treatments compared to control. Also pigments of photosynthetic and membrane stability were more stable with the best treatments compared with untreated plants. Furthermore, the levels of CKs, IAA and GA3 were increased in treated plants, while, ABA decreased in both cut 'Anna and Gold strike' rose flowers compared untreated plants. Overall, the results suggest that SA and combination of ethanol + sucrose increase vase life by improving the antioxidant system and endogenous growth hormones and reducing oxidative stress damages during rose flower senescence. In general, Gold strike cv. was more responsive than Anna cv. to proposed transactions. On the other hand, the lowest coefficients were STS, 5-SSA and BA treatments.
\end{abstract}

Key words: Vase life, salicylic acid, sucrose, ethanol, antioxidant, IAA, CKs, GA3 and ABA.

\section{INTRODUCTION}

Rose (Rosa hybrida L.), one of the valuable cut flowers, belongs to the Rosaceae family which has dedicated fourth ranking of production (Butt, 2003). Egypt is one of the countries classified as the most appropriate environmental conditions, the soil, climate and

\footnotetext{
* Corresponding author: Tel. : +201013245103

E-mail address: mahmoud46544654@gmail.com
}

trained labors to produce cut flower crops for local markets and for export. However, the short vase life could be one of the most important reasons for inability of florists to develop an appreciable to use market in Egypt. Petals senescence commonly is accompanied by morphological, biochemical deterioration as declining protein concentration, membrane 
damage, and an increase in protease activity (Arora et al., 2007). Furthermore, it was also confirmed that reactive oxygen species (ROS) is involved in plant tissues (Dhindsa et al., 1981). The first part of this study, was reported that the vase life in Anna cv. was early senescence (short-longevity, 4 days) when compared with Gold strike cv. recorded late senescence (longlongevity, 8 days). Gold strike showed better for water relation (water uptake, water loss and relative fresh weight), photosynthetic pigments constancy, membrane stability as well, also less oxidative products as $\mathrm{H}_{2} \mathrm{O}_{2}$ and TBARS and have appearing of defense system by antioxidant enzymes as POD and SOD activity. Furthermore, it was clearly better endogenous hormones as GA3, CKs and IAA, when compared with ABA in Anna cv. (El-Nabarawy et al., 2018). Earlier studies reported that preservation solution for delaying senescence and extending flower vase life contain germicides, ethylene synthesis inhibitors, growth regulators, some mineral compounds, and carbohydrates that are essential for extending the vase life of cut flowers (Halevy and Mayak, 1981). Sulfosalicylic acid as salicylate derivatives in vase solution was most effective in extending flower vase life of cut gladiolus. Salicylates increased vase life by increasing reactive oxygene species (ROS) scavenging activity of the gladiolus cut flowers (Ezhilmathi et al., 2007). In recent years, SA has been the focus of intensive research due to its function as an endogenous signal mediating local and systemic plant defense responses against pathogens. It has also been found that SA plays a role during the plant response to abiotic stresses such as drought, chilling heavy metal toxicity, heat and osmotic stress. SA appears to be, just like in mammals an "effective therapeutic agent" for plants (Marina and Javier, 2011). Cut rose flower has short vase life that relates to the ethylene production and causes wilting, bent neck and vascular blockage by air and microorganisms (Van Doorn, 1997). All this confirms the fact that SA is a natural, cheap, safe, and a biodegradable compound which is a suitable alternative for conventional chemical treatments to prolong vase life of cut rose flowers (Abdolmaleki et al., 2015). The treatment with distilled water (as a control) gave the shortest vase life period that was characterized by poor water relations in association with lower water uptake (probably due to growth of microbes and vascular blockage), high rate of transpiration and water loss, as noticed by Mehraj et al. (2016). Preservative and antiethylene compounds (biocide and germicide) such as ethanol prevent vascular blockage (Singh and Tiwari, 2002). Ethanol is one of the anti-ethylene compounds that reduces ethylene activity and increases vase life of cut flowers (Farrokhzad et al., 2005). Furthermore, ethanol and acetaldehyde with Allamanda cathartica var. Grandiflora showed that delayed leaves chlorosis and extended vase life (Umbese, $\boldsymbol{e t}$ al., 2010). Carbohydrate one of the preservatives solutions to delay the senescence and provide a respiratory substrate. However, carbohydrate especially sucrose cause growth and increased in bacterial amounts, existing in preservative solution, which tend to embolism of cut flower xylem vessel (Kaltaler and Steponkus, 1976). In present study (senescence flowers of roses: 1Comparison between Anna and Gold strike cvs.) reported that Anna cv. have the short-longevity vase life (early senescence) and Gold strike cv. which have long-longevity (late senescence). In this part of the study, was to investigate an attempt to regulate and delay aging in both Anna and Gold strike cvs. Rose flowers by chemical holding treatments including Suc, Eth, Eth+Suc, SA, 5-SSA, STS and BA. In general, SA, Eth and Eth+Suc recorded better of the vase life compared with other treatments. Furthermore, Gold strike cv. was move responsive than Anna cv. to proposed transactions. On the other hand, the lowest coefficients were Suc, STS, 5-SSA and BA treatments.

\section{MATERIALS AND METHODS}

\section{Plant Material}

Rosa hybrida L. cultivars used in the investigation were Anna and Gold strike cvs. in open bud stage cut in the early morning, from a local commercial greenhouse (Floramix Farm, El-Mansuria District-Giza-Egypt), wrapped in Kraft paper in groups and transported with appropriate covers immediately to laboratory of Plant Physiology, Faculty of Agriculture, AlAzhar University, Nasr city Cairo, Egypt during 2013 - 2016 A.D. Keep only five upper leaves of each flowery stem, and the stems were placed in vases after re-cutting (removing about $10 \mathrm{~cm}$ ) in the air. Two stems (subsamples) from each 
cultivar were placed in a jar containing $350 \mathrm{ml}$, three jars from each cultivar were untreated and treated by chemical preservatives, Suc $(1,2$ and $3 \%)$, Eth (4, 6 and 8\%), Eth+Suc $(4+2,6+2,8+2$ and $10+3$, respectively), SA $(0.5,1.0$ and 2.0 $\mathrm{mM}), 5$-SSA $(250,500$ and $750 \mu \mathrm{M})$, STS $(5,10$ and $15 \mathrm{ppm})$ and $\mathrm{BA}(5,10$ and $15 \mu \mathrm{M})$. The experiments maintained under condition $23-25^{\circ} \mathrm{C} /$ $60-70 \%$ Relative humidity and with light intensity (1000 $\mu \mathrm{w} / \mathrm{cm}^{2}$ in 12 hours' photoperiods) supplied from white fluorescent tubes.

\section{Measurement of Vase Life}

Vase life was recorded as the number of days on vase (according to Liao et al., 2000).

\section{Measurement of water relation}

Water uptake, water loss, water balance and relative fresh weight was measured according to El-Quesni et al. (2009).

\section{Electrolyte leakage (EL)}

Ion leakage was determined as electrical conductivity (EC\%) according to Hassanein $\boldsymbol{e t}$ al. (2012).

\section{Membrane stability index (MSI)}

For determination of cell membrane stability (MSI) was estimated from the formula: MSI = [1-EC1/EC2] x100. (Sairam and Tyagi, 2004).

Determination of chlorophyll $a, b$ and total carotenoid concentrations

Chlorophyll a (Chl-a), Chlorophyll b (Chl-b) and total carotenoids $(\mathrm{Cx}+\mathrm{c})$ levels (Methanol solvent) were calculated according to the formulas of Lichtenthaler and Wellburn (1985).

$$
\begin{aligned}
& \text { Chl-a }=15.65 \text { A666 - 7.340 A653 } \\
& \text { Chl-b }=27.05 \text { A653 - 11.21 A666 } \\
& \mathrm{Cx}+\mathrm{c}=1000 \text { A470 }-2.860 \mathrm{Ca}-129.2 \mathrm{Cb} / 245 .
\end{aligned}
$$

\section{Determination hydrogen peroxide $\left(\mathrm{H}_{2} \mathrm{O}_{2}\right)$}

$\mathrm{H}_{2} \mathrm{O}_{2}$ determination of leaves and petals tissue determined using the extinction coefficient $0.28 \mu \mathrm{M}-1 \quad \mathrm{~cm}-1$ and amount expressed as nmol g-1 f.W were calculated according to Velikova et al. (2000).

Determination of thiobarbituric acid reactive substance (TBARS concentration) and measurement level of lipid peroxidation:
Thiobarbituric acid-reactive substances (TBARS) were measured in plant homogenate using the method of Ohkawa et al. (1979).

\section{Determination of Antioxidant Enzymes Activity}

Tissue preparation for enzymatic antioxidants

fresh leaves and petals samples $(0.2 \mathrm{~g})$ were ground in liquid $\mathrm{N}_{2}$ and homogenized in an icebath in $4 \mathrm{ml}$ homogenizing solution containing $50 \mathrm{mM}$ potassium phosphate buffer and $1 \%$ $(W / V)$ polyvinylpyrrolidone $(\mathrm{pH}$ 7.8). The homogenate was centrifuged at $14000 \mathrm{rpm}$ at $4^{\circ} \mathrm{C}$ for $10 \mathrm{~min}$ and the resulting supernatant was used for enzyme assays.

\section{Determination of peroxidase (POD)}

POD activity was measured according the method of Chance and Maehly (1955).

\section{Determination of superoxide dismutase (SOD) activity}

SOD activity was measured according the method of Beyer and Fridovich (1987).

\section{Determination of endogenous hormones}

IAA, CKs, GA3 and ABA were measured by the injection of the extract into a reverse phase HPLC, with a methanol gradient in $0.6 \%$ acetic acid according to Chen and Yang (2005).

\section{Statistical Analysis}

Data were subjected to analysis of variance (ANOVA) and significant differences among means were calculated by Duncan's multiple range test $(\mathrm{p} \leq 0.05)$. All data were analyzed statistically by one-way ANOVA using the CoStat program version 6.3 (Costat, 1990).

\section{RESULTS AND DISCUSSION}

\section{Vase Life}

Results regarding rose flowers average longevity is tabulated in Table 1. Gold Strike cv. has showed longer vase life than Anna cv. for control and all the treatments. Also, the best treatments which significantly increased vase life in Gold strike cv. Were SA at $1 \mathrm{mM}$ which recorded 12 days pursue by 11 days with $0.5 \mathrm{Mm}$ SA, $6 \%$ Eth and $2 \%$ Suc $+6 \%$ Eth treatments and besides that it decreased floret abscission 


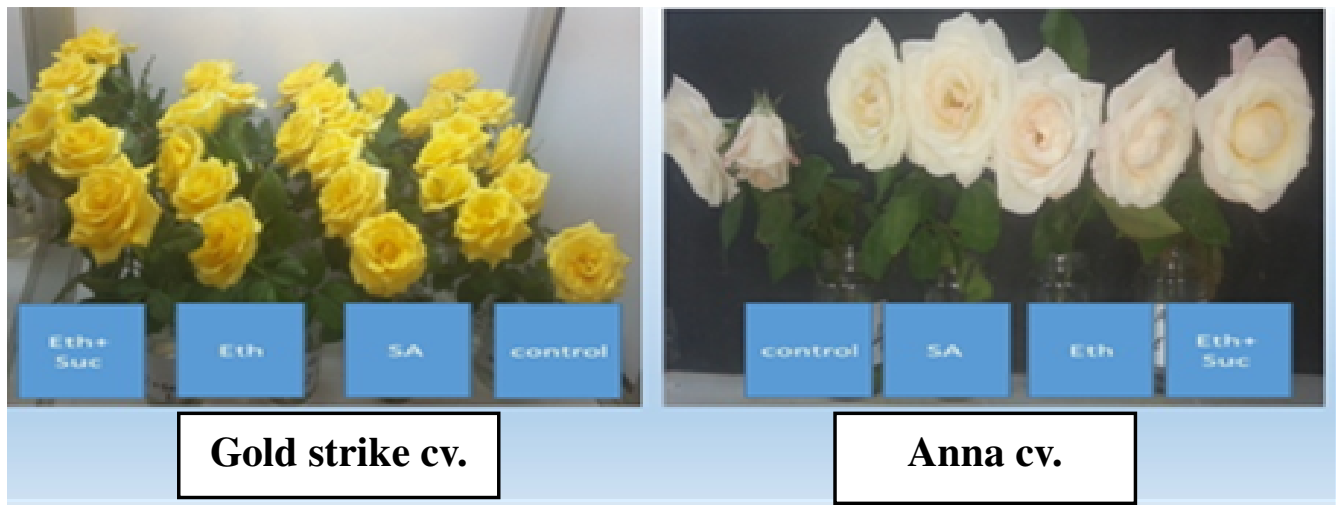

Fig. 1. Effect of different preservative solutions (Suc, Eth, Eth+Suc, SA, 5-SSA, STS and BA) on vase life (days) of cut 'Anna and Gold strike' rose flowers

Table 1. Effect of different preservative solutions (Suc, Eth, Eth+Suc, SA, 5-SSA, STS and BA) on vase life (days) of cut 'Anna and Gold strike' rose flowers

\begin{tabular}{|c|c|c|}
\hline \multirow[t]{2}{*}{ Treatment } & \multicolumn{2}{|c|}{ Vase life (day) } \\
\hline & Anna cv. & Gold strike cv. \\
\hline Untreated & 4 & 8 \\
\hline \multicolumn{3}{|l|}{ Suc } \\
\hline $1 \%$ & 4 & 6 \\
\hline $2 \%$ & 4 & 7 \\
\hline $3 \%$ & 3 & 6 \\
\hline \multicolumn{3}{|l|}{ Eth } \\
\hline $4 \%$ & 5 & 9 \\
\hline $6 \%$ & 6 & 11 \\
\hline $8 \%$ & 4 & 8 \\
\hline \multicolumn{3}{|l|}{ Suc + Eth } \\
\hline $2 \%$ Suc $+4 \%$ Eth & 5 & 9 \\
\hline $2 \%$ Suc $+6 \%$ Eth & 6 & 11 \\
\hline $2 \%$ Suc $+8 \%$ Eth & 5 & 7 \\
\hline $3 \%$ Suc + 10 Eth & 3 & 5 \\
\hline \multicolumn{3}{|l|}{ (- } \\
\hline $0.5 \mathrm{mM}$ & 5 & 11 \\
\hline $1 \mathrm{mM}$ & 7 & 12 \\
\hline $2 \mathrm{mM}$ & 5 & 9 \\
\hline \multicolumn{3}{|l|}{ 5-SSA } \\
\hline $250 \mu \mathrm{M}$ & 5 & 9 \\
\hline $500 \mu \mathrm{M}$ & 5 & 9 \\
\hline $750 \mu \mathrm{M}$ & 4 & 8 \\
\hline \multicolumn{3}{|l|}{ STS } \\
\hline 5 ppm & 3 & 5 \\
\hline 10 ppm & 4 & 5 \\
\hline $15 \mathrm{ppm}$ & 3 & 4 \\
\hline \multicolumn{3}{|l|}{ BA } \\
\hline $5 \mu \mathrm{M}$ & 5 & 7 \\
\hline $10 \mu \mathrm{M}$ & 5 & 8 \\
\hline $15 \mu \mathrm{M}$ & 4 & 6 \\
\hline
\end{tabular}


as compared to control ( 8 days). The better treatments were observed in Anna cv. with SA at $1 \mathrm{mM}$ followed by ethanol $6 \%$ which recorded 7 and 6 days, respectively when compared with the control (4 days). While, minimum vase life was recorded with all concentrations of sucrose (Suc) at 1,2 and 3\%, ethanol (Eth) at 4 and $8 \%$, sucrose + ethanol (Suc+Eth) at Suc $2 \%+$ Eth $4 \%, 2$ Suc $2 \%+$ Eth $8 \%$ and Suc $3 \%+$ Eth $10 \%$, salicylic (SA) at 0.5 and $2 \mathrm{mM}$, 5sulphosalyciclc acid (5-SSA) at 250,500 and 750 $\mu \mathrm{M}$, silver thiosulphate (STS) at 5,10 and 15 ppm and benzyladenine (BA) at 5,10 and $15 \mu \mathrm{M}$ on both cultivars. Vase life was improved by using SA in vase solutions. SA extended vaselife of cut rose flowers by regulating water uptake. Also, adding SA to vase water has previously been shown to extend the longevity of cut Rosa flowers (Capdeville et al., 2003; Ping et al., 2004). Additionally, Fan et al. (2008) showed that the treatment of salicylic acid extended the vase life and improved flower quality with reduced respiration rate delay senescence and decrease lipid peroxidation, malondialdehyde (MDA) concentration, in addition (Han, 2003; Yamane et al., 2005) came to similar findings. Our results with ethanol treatment, confirmed by other researches (Farrokhzad et al., 2005; Sharif-Hossain et al., 2007). Also, vase solutions include 6\% (Eth) ethanol showed increase in vase life on Alstroemeria compared to the control (Kiaseh and Yadegari, 2016). Treatment of cut carnation flowers with low concentrations of ethanol increases their vase life significantly (Heins, 1980; Wu et al., 1992). Podd and Staden (2004) stated that carnation flower senescence was delayed by ethanol. Low concentrations of ethanol significantly increased the vase life of cut carnation flowers (Serrano et al., 1991; Mayak and Triosh, 1993). Moreover, Pun et al. (1999) reported that ethanol (4 and 6\%) increased the vase life of' carnation flowers and cultivars showed variable response to ethanol treatment about to vase life increment.

They also mentioned that treatment with $4 \%$ ethanol inhibited ethylene production as well as sensitivity to ethylene and responsive to ethanol. For ethanol and sucrose treatment, sucrose at $2 \%$ showed that vase solution (containing 2\% sucrose) prolonged the vase life of cut clematis (Je-drzejuk et al., 2016). The ethanol may act as an energy source or reduce the requirement for carbohydrates in the flower. Sucrose was not supplied to the flowers with the ethanol in the holding-solution, but when added in preliminary experiments, no benefit was obtained (Mayak and Kofranek, 1976).

\section{Effect of Treatments}

\section{Water uptake of flowers}

The perusal of data, Table 2 indicated that, the SA $1 \mathrm{mM}$ and $6 \% \mathrm{Eth}+2 \%$ Suc treatments showed significant influence on water uptake in both 'Anna and Gold strike' cvs. compared with control (untreated flowers). The highest uptake was observed in Anna cv. which recorded 12.11 and $10.83 \mathrm{ml} /$ flower but for Gold strike cv. the values were 9.53 and $8.36 \mathrm{ml} /$ flower compared with control which recorded $(9.11$ and $7.45 \mathrm{ml} /$ flower) at 3-4 and 7-8 days during their vase life with Anna and Gold strike cvs., respectively. Solution uptake amounts SA-treated in Gerbera cut flowers were significantly more than control. The results agree with Vahdati et al. (2012) who showed that SA enhancing water uptake and relative fresh weight of cut flowers. The improvement in vase life of cut flowers treated by SA may be due to antimicrobial activity (inhibiting vascular blockage), increases the water uptake (Mori et al., 2001) and decrease in transpiration rate (Mei-hua et al., 2008), maintance enhancing water balance of cut flowers. The results agree with Hamidi-Imani et al. (2013) who showed that ethanol improved solution uptake of cut Rose (Rosa hybrida L. cv. 'Avalanche').

Also, Nematollah-Sani et al. (2010) found that the $6 \%$ of ethanol had positive effect on water uptake in Anthurium andreanum cut flowers. Ethanol in higher level increased solution uptake compared to the control in cut Carnation (Dianthus caryophyllus L.) as reported by Asgari and Moghadam (2015).

\section{Water loss of flowers}

During the entire period of observation transpiration water loss in the flowers was found to have profound influence by $1 \mathrm{mM} \mathrm{SA}$ and $6 \%$ Eth treatments in both 'Anna and Gold strike' cvs. Table 2, exhibited significant influence on water loss which recorded maximum in Anna cv. at 3-4 days during vase life which recorded (10.10 and $9.98 \mathrm{ml} /$ flower) compared with control which recorded ( $8.57 \mathrm{ml} /$ flower). Whereas 
Table 2. Effect of the best treatments (1mM SA, 6\% Eth and 6\% Eth + 2\% Suc) on water relations (water uptake, water loss, water balance and relative fresh weight) for "Anna and Gold strike' cvs of cut rose flowers during their vase life

\begin{tabular}{|c|c|c|c|c|c|c|c|c|}
\hline \multirow[t]{3}{*}{ Treatment } & \multicolumn{4}{|c|}{ Anna cv. } & \multicolumn{4}{|c|}{ Gold strike cv. } \\
\hline & \multicolumn{4}{|c|}{ Vase life/day } & \multicolumn{4}{|c|}{ Vase life/day } \\
\hline & $1-2$ & $3-4$ & $5-6$ & $7-8$ & $1-2$ & $3-4$ & $5-6$ & $7-8$ \\
\hline \multicolumn{9}{|c|}{ Water uptake (ml/flower) } \\
\hline Untreated & 12.05 & 9.11 & - & - & 13.27 & 10.00 & 9.02 & 7.45 \\
\hline 1mM SA & 13.01 & 12.11 & - & - & 15.37 & 14.32 & 11.33 & 9.53 \\
\hline $6 \%$ Eth & 13.17 & 10.73 & - & - & 14.73 & 13.63 & 10.21 & 8.36 \\
\hline $6 \%$ Eth + Suc $2 \%$ & 13.89 & 10.83 & - & - & 16.11 & 10.52 & 10.01 & 8.25 \\
\hline LSD $5 \%$ & \multicolumn{8}{|c|}{2.98} \\
\hline \multicolumn{9}{|c|}{ Water loss (ml/flower) } \\
\hline Untreated & 13.45 & 8.57 & - & - & 14.23 & 9.95 & 8.52 & 7.15 \\
\hline $1 \mathrm{mM} S A$ & 11.66 & 10.10 & - & - & 13.93 & 12.22 & 11.65 & 9.53 \\
\hline $6 \%$ Eth & 12.57 & 9.98 & - & - & 13.23 & 12.12 & 9.07 & 8.66 \\
\hline $6 \%$ Eth + Suc $2 \%$ & 14.39 & 9.04 & - & - & 15.96 & 11.67 & 8.35 & 6.26 \\
\hline LSD 5\% & & & & 4.29 & & & & \\
\hline \multicolumn{9}{|c|}{ Water balance (ml/flower) } \\
\hline Untreated & -1.4 & 0.54 & - & - & -0.96 & 0.05 & 0.5 & 0.3 \\
\hline 1mM SA & 1.35 & 2.01 & - & - & 1.44 & 2.1 & -0.32 & 0 \\
\hline $6 \%$ Eth & 0.6 & 0.75 & - & - & 1.5 & 1.51 & 1.14 & -0.3 \\
\hline $6 \%$ Eth + Suc $2 \%$ & -0.5 & 1.79 & - & - & 0.15 & -1.15 & 1.66 & 1.99 \\
\hline LSD $5 \%$ & & & & -2.6 & & & & \\
\hline \multicolumn{9}{|c|}{ Relative fresh weight $(\%)$} \\
\hline Untreated & 103.60 & 97.80 & - & - & 105.50 & 98.50 & 98.30 & 95.00 \\
\hline $1 \mathrm{mMSA}$ & 106.50 & 97.40 & - & - & 108.40 & 100.90 & 101.90 & 98.10 \\
\hline $6 \%$ Eth & 108.70 & 101.30 & - & - & 112.10 & 102.10 & 100.40 & 89.40 \\
\hline $6 \%$ Eth + Suc $2 \%$ & 105.74 & 104.22 & - & - & 108.80 & 99.89 & 102.29 & 97.20 \\
\hline LSD $5 \%$ & & & & LSD 5\% & & & & \\
\hline
\end{tabular}


water loss, recorded (9.53 and $8.66 \mathrm{ml} /$ flower) for both treatments at 7-8 days during vase life compared with control in the same days which recorded ( $7.15 \mathrm{ml} /$ flower) with Gold strike cv. The results agree with Lu et al. (2010) who reported that the water loss of cut rose flowers increased significantly after harvest with SA treated. On the other hand, it was assumed that the effect of SA treatment which caused lower water loss could be due to the increasing water uptake (Raskin, 1992) as well as decrease in transpiration rate (Mei-hua et al., 2008).

\section{Water balance of flowers}

The perusal of data in Table 2, water balance at 3-4 days during vase life, $1 \mathrm{mM} \mathrm{SA}$ and $6 \%$ Eth $+2 \%$ Suc treatments showed more positive water balance in Anna cv. which recorded (2.01 and $1.79 \mathrm{ml} /$ flower) compared to control which recorded $(0.54 \mathrm{ml} /$ flower $)$. While, with Gold strike cv. at 7-8 days during vase life, more positive water balance with $6 \%$ Eth $+2 \%$ Suc was detected on Gold strike cv. which recorded (1.99 $\mathrm{ml} /$ flower) compared with control which recorded $(0.3 \mathrm{ml} /$ flower). The results are similar with Lu et al. (2010) who showed that the water balance decreased significantly and reduction in the water balance during vase period. Also, Soleimany-Fard et al. (2013) showed that SA treatment had the highest amount of water balance and control treatment had the lowest water balance concentration during vase life.

\section{Relative fresh weight (RFW) of flowers}

During the entire period of observation on Table 2. Vase life was RFW on both 'Anna and Gold strike' cvs. cut flower was found the maximum relative fresh weight with $6 \%$ Eth + $2 \%$ Suc and $6 \%$ Eth treatments which recorded (104.22 and $101.30 \%$ respectively) at 3-4 days in Anna cv. compared to control was recorded (97.80\%). While, in Gold strike cv. recorded maximum RFW with $1 \mathrm{mM} \mathrm{SA}$ and $6 \%$ Eth + $2 \%$ Suc was recorded (98.10 and $97.20 \%$ ) at 7-8 days. compared to control which recorded (95.00\%). The results confirmed by Bayat and Aminifard (2017) reported that SA treated with Alstroemeria peruviana, Gerbera jamesonii, Lilium asiaticum, Rosa hybrida and Polianthes tuberose influenced significantly on RFW. Results are in line with those of Hajizadeh et al. (2012) who reported that RFW of flowers had a decreasing trend during vase life and the lowest value was observed in control at the end of vase life in Rosa hybrid cv. Black magic. The increment in RFW at initial vase life days could be due to the higher solution uptake during the early storage time as supported by Seyf $\boldsymbol{e t}$ al. (2012) who found that because of more water absorption, aluminum treated flowers of cut rose 'Boeing' had more RFW than control. The declined RFW during prolonged storage time might be due to high water loss and the declining solution uptake salicylic acid can be decreased $\mathrm{pH}$ of vase solution and consequently, the growth and proliferation of bacteria was reduced, which led to increase water uptake (Raskin, 1992). Furthermore, Kazemi and Ameri (2012) showed that the treated cut Gerbera flowers with SA had the highest levels of RFW during vase period.

\section{Effect of Treatments on Membrane Stability and Electrolyte Leakage}

\section{Membrane stability index (MSI)}

The maximum MSI were detected under 1 $\mathrm{mM}$ SA, 6\% Eth and 6\% Eth $+2 \%$ Suc treatment, which recorded $(65.5,62.16$ and $59.99 \%$ respectively) in leaves. While, recorded (75.79, 76.18 and $76.64 \%$ respectively) in petals in to Anna cv. treated at $4^{\text {th }}$ day, Table 3. Also, so well recorded in Gold strike cv. treated (72.44, 65.21 and $72.41 \%$, respectively) in leaves $(78.53,76.46$, and $79.12 \%$ respectively) in petals. The results agree with Mei-hua et al., (2008) showed that SA can extend the vase life of cut flowers with increase membrane stability.

\section{Electrolyte leakage (EL)}

Data depicted the results at $4^{\text {th }}$ day of vase life indicate that decreasing E.L were detected under treated by $1 \mathrm{mM} \mathrm{SA}, 6 \%$ Eth $+2 \%$ Suc and $6 \%$ Eth respectively compared to control on both 'Anna and Gold strike' cultivars cut Rose flowers. E.L values, Table 3 which recorded in Anna treated on leaves $(33.49,36.84$ and $32.01 \%$ respectively) compared to control $(38.89 \%)$. 
Table 3. Effect of best treatments (1mM SA, $6 \%$ Eth, $6 \%$ Eth $+2 \%$ Suc) on membrane stability and electrolyte leakage of cut 'Anna and Gold strike' Rose flowers during their vase life

\begin{tabular}{|c|c|c|c|c|c|c|c|c|c|c|c|c|}
\hline Cultivar & \multicolumn{6}{|c|}{ Anna } & \multicolumn{6}{|c|}{ Gold strike } \\
\hline \multicolumn{13}{|c|}{ Membrane stability index (\%) } \\
\hline Plant organ & \multicolumn{3}{|c|}{ Leaves } & \multicolumn{3}{|c|}{ Petals } & \multicolumn{3}{|c|}{ Leaves } & \multicolumn{3}{|c|}{ Petals } \\
\hline Vase life/day & 0 & 4 & 8 & 0 & 4 & 8 & 0 & 4 & 8 & 0 & 4 & 8 \\
\hline Control & 70.53 & 61.11 & 56.5 & 81.2 & 71.05 & 61.1 & 72.65 & 64.92 & 45.11 & 86.72 & 75.43 & 63.83 \\
\hline $1 \mathrm{mM} S A$ & - & 65.5 & 55.86 & - & 75.79 & 74.03 & - & 72.44 & 50.07 & - & 78.53 & 61.39 \\
\hline $6 \%$ Eth & - & 62.16 & 55.97 & - & 76.18 & 63.4 & - & 65.21 & 48.87 & - & 76.46 & 57.22 \\
\hline $6 \%$ Eth $+2 \%$ Suc & - & 59.99 & 51.39 & - & 76.64 & 74.33 & - & 72.41 & 54.33 & - & 79.12 & 65.34 \\
\hline \multicolumn{13}{|c|}{ Electrolyte leakage (\%) } \\
\hline Control & 29.47 & 38.89 & 43.5 & 25.8 & 33.57 & 40.9 & 27.35 & 35.07 & 54.88 & 13.29 & 28.95 & 38.89 \\
\hline $1 \mathrm{mM} \mathrm{SA}$ & - & 33.49 & 41.15 & - & 24.21 & 35.97 & - & 31.93 & 50.79 & - & 24.47 & 33.61 \\
\hline $6 \%$ Eth & - & 36.84 & 42.03 & - & 23.82 & 41.6 & - & 33.13 & 53.55 & - & 26.54 & 42.78 \\
\hline $6 \%$ Eth $+2 \%$ Suc & - & 32.01 & 40.61 & - & 25.67 & 36.59 & - & 29.36 & 46.67 & - & 23.88 & 34.66 \\
\hline LSD 5\% & & & LSI & Leave & $\mathrm{s} 0.05=$ & 7.029 & $\& \quad$ LS & Petals & $0.05=9$ & & & \\
\hline
\end{tabular}

Also, was recorded on petals $(24.21,23.82$ and $25.67 \%$, respectively) compared with control $(33.57 \%)$. But it recorded in Gold strike cv. treated on leaves $(31.93,33.13$ and $29.36 \%$ respectively) compared with control $(35.07 \%)$ also showed lowest E.L. with better treated as SA, (Eth +Suc) and Eth $(24.47,26.54$ and $23.88 \%$, respectively) compared to control $(28.95 \%)$ in petals. These results are in agreements with Rahmani et al. (2015) who reported that SA significantly increased flower membrane stability and anthocyanins amount at the biochemical level, senescence is associated with changes in membrane fluidity and leakage of ions in several different flowers. Rao et al. (1997) suggested that $\mathrm{SA}$ can generate $\mathrm{H}_{2} \mathrm{O}_{2}$ and inflicting oxidative damage to membranes and proteins. Also, Jaleel et al. (2007) in Catharanthus Roseus and Yusuf et al. (2007) in Brassica juncea. Also, Rao et al. (2012) reported that, the membrane stability index of maize plants was, mostly, highly significantly increased in response to the treatment with SA and drought stress. Foliar application of SA decreased electrolyte leakage of leaves. So that, electrolyte leakage of leaves, indicating cell membrane damage is simply because membrane lipid peroxidation in the presence of reactive oxygen species.

\section{Effect of Treatments on Pigments (Chlorophylls and Carotenoids)}

Both cultivars showed a linear decrease in all pigments over time during the vase life (Table 4). The previous treatments lead to a considerable delay in degradation of $\mathrm{Chl} \mathrm{a,b}$ and carotenoids compared to control in both the cultivars Anna and Gold strike cv. The highest pigments stability index was maintenance with $1 \mathrm{mM} \mathrm{SA}$, $6 \%$ Eth $+2 \%$ Suc when recorded (112.65 and $106.90 \%)$ on Anna cv. compared with control $(73.86 \%)$. Same results were observed with Gold strike cv. (134.32 and 149.58\%) respectively, compared with control $(95.45 \%)$. While for pigments degradation index chlorophyll $\mathrm{a}$ and $\mathrm{b}$ recorded lowest breakdown with SA $1 \mathrm{mM}, 6 \%$ Eth $+2 \%$ Suc at $4^{\text {th }}$ day. Furthermore, carotenoids recorded same percentage of stability on both 
Zagazig J. Agric. Res., Vol. 45 No. (3) 2018

Table 4. Effect of best treatments (1mM SA, $6 \%$ Eth and $6 \%$ Eth $+2 \%$ Suc) on chlorophyll A, B and carotenoids of cut 'Anna and Gold strike' Rose flowers during their vase life

\begin{tabular}{|c|c|c|c|c|c|c|c|c|c|c|c|c|c|c|c|}
\hline \multirow{3}{*}{$\begin{array}{l}\text { Pigment } \\
\text { Cultivar } \\
\text { Vase life/day }\end{array}$} & \multicolumn{5}{|c|}{ Chl. (A) mg/g.F.W } & \multicolumn{5}{|c|}{ Chl. (B) mg/g.F.W } & \multicolumn{5}{|c|}{ Cx+c. mg/g.F.W } \\
\hline & \multicolumn{2}{|c|}{ Anna } & \multicolumn{3}{|c|}{ Gold strike } & \multicolumn{2}{|c|}{ Anna } & \multicolumn{3}{|c|}{ Gold strike } & \multicolumn{2}{|c|}{ Anna } & \multicolumn{3}{|c|}{ Gold strike } \\
\hline & $\mathbf{0}$ & 4 & $\mathbf{0}$ & 4 & 8 & $\mathbf{0}$ & 4 & $\mathbf{0}$ & 4 & 8 & $\mathbf{0}$ & 4 & $\mathbf{0}$ & 4 & 8 \\
\hline ntreated & 12.89 & 9.52 & 11.86 & 11.32 & 10.9 & 3.06 & 1.14 & 1.52 & 1.41 & 1.52 & 2.69 & 2.43 & 3.39 & 3.05 & 1.9 \\
\hline $1 \mathrm{mMSA}$ & 12.89 & 14.52 & 11.86 & 15.93 & 15.15 & 3.06 & 1.72 & 1.52 & 1.32 & 0.88 & 2.69 & 3.37 & 3.39 & 4.12 & 4.24 \\
\hline 6\% Eth & 12.89 & 12.33 & 11.86 & 10.66 & 8.36 & 3.06 & 1.24 & 1.52 & 0.86 & 0.64 & 2.69 & 2.7 & 3.39 & 3.19 & 2.63 \\
\hline $6 \%$ Eth $+2 \%$ Suc & 12.89 & 13.78 & 11.86 & 17.74 & 16.61 & 3.06 & 3.62 & 1.52 & 1.7 & 1.86 & 2.69 & 2.84 & 3.39 & 4.68 & 4.19 \\
\hline LSD $5 \%$ & & & 1.86 & & & & & 1.552 & & & & & 1.079 & & \\
\hline \multicolumn{16}{|c|}{ Pigments stability index (\%) } \\
\hline Vase life/days & 0 & 4 & 0 & 4 & 8 & 0 & 4 & 0 & 4 & 8 & 0 & 4 & 0 & 4 & 8 \\
\hline Untreated & 100 & 73.86 & 100 & 95.45 & 91.91 & 100 & 37.25 & 100 & 92.76 & 100.00 & 100 & 90.33 & 100 & 89.97 & 56.05 \\
\hline $1 \mathrm{mMSA}$ & 100 & 112.65 & 100 & 134.32 & 127.74 & 100 & 56.21 & 100 & 86.84 & 57.89 & 100 & 125.28 & 100 & 121.53 & 125.07 \\
\hline 6\% Eth & 100 & 95.66 & 100 & 89.88 & 70.49 & 100 & 40.52 & 100 & 56.58 & 42.11 & 100 & 100.37 & 100 & 94.10 & 77.58 \\
\hline $6 \%$ Eth $+2 \%$ Suc & 100 & 106.90 & 100 & 149.58 & 140.05 & 100 & 118.30 & 100 & 111.84 & 122.37 & 100 & 105.58 & 100 & 138.05 & 123.60 \\
\hline \multicolumn{16}{|c|}{ Pigments degradation index (\%) } \\
\hline Vase life/ & 0 & 4 & 0 & 4 & 8 & 0 & 4 & 0 & 4 & 8 & 0 & 4 & 0 & 4 & 8 \\
\hline Untreated & 100 & 26.14 & 100 & 4.55 & 8.09 & 100 & 62.75 & 100 & 7.24 & 0.00 & 100 & 9.67 & 100 & 10.03 & 43.95 \\
\hline $1 \mathrm{mMSA}$ & 100 & -12.65 & 100 & -34.32 & -27.74 & 100 & 43.79 & 100 & 13.16 & 42.11 & 100 & -25.28 & 100 & -21.53 & -25.07 \\
\hline 6\% Eth & 100 & 4.34 & 100 & 10.12 & 29.51 & 100 & 59.48 & 100 & 43.42 & 57.89 & 100 & -0.37 & 100 & 5.90 & 22.42 \\
\hline $6 \%$ Eth+2\% Suc & 100 & -6.90 & 100 & -49.58 & -40.05 & 100 & -18.30 & 100 & -11.84 & -22.37 & 100 & -5.58 & 100 & -38.05 & -23.60 \\
\hline
\end{tabular}

Anna and Gold strike cvs., with SA $1 \mathrm{mM}$, Eth + Suc with (121.53 and $138.05 \%)$, respectively compare as control (89.97\%) in Gold strike cv., while recorded (125.28 and $105.58 \%)$, respectively compared with control $(90.33 \%)$ with Anna cv. The application of SA $1 \mathrm{mM}, 6 \%$ Eth $+2 \%$ Suc increased chlorophyll a concentration.

The concentration of chlorophyll $a$ was higher than chlorophyll $\mathrm{b}$ at any time throughout the vase life. These findings are similar to previous results (Jamali and Rahemi, 2011; Kazemi et al., 2011 a,b). It has been shown that leaves chlorophyll concentration decreases during senescence (Tang et al., 2005; Ferrante et al., 2009; Guiboileau et al., 2010). The greatly increased chlorophyll concentration by sucrose in auxin-induced growth of Tulip stem segments, may be caused by delaying of senescence, increased chlorophyll biosynthesis or retarded chlorophyll degradation. It is well known that sugars prevent senescence of cut flowers and vegetables, Sucrose improved the postharvest life of cut flowers of Limonium (Doi and Reid, 1995), Liatris (Han, 2001), Eustoma grandiflorum (Cho et al., 2001), and many other species. Sucrose supply increased longevity and inhibited chlorophyll degradation of Broccoli (Brassica oleracea) branchlets Irving and Joyce (1995).

\section{Effect of Treatments on Oxidative Production $\left(\mathrm{H}_{2} \mathrm{O}_{2}\right.$ and TBARS)}

The perusal of data in Table 5 showed that the concentration of oxidative compounds such as free non-radicals based on oxygen, as well as 
Table 5. Effect of treatments (1mM SA, $6 \%$ Eth and $6 \%$ Eth $+2 \%$ Suc) on hydrogen peroxide $\left(\mathrm{H}_{2} \mathrm{O}_{2}\right)$ and thiobarbituric acid reactive substances (TBARS) in leaves and petals of cut 'Anna and Gold strike' Rose flowers

\begin{tabular}{|c|c|c|c|c|c|c|c|c|c|c|}
\hline \multicolumn{6}{|c|}{$\mathrm{H}_{2} \mathrm{O}_{2}(\mathrm{nmol} / \mathrm{g} \mathrm{F.W})$} & \multicolumn{5}{|c|}{ TBARS (nmol/g F.W) } \\
\hline \multirow{2}{*}{ Treat. } & \multirow{2}{*}{$\begin{array}{l}\text { Vase } \\
\text { life/ } \\
\text { day }\end{array}$} & \multicolumn{2}{|c|}{ Anna } & \multicolumn{2}{|c|}{ Gold strike } & \multirow{2}{*}{$\begin{array}{l}\text { Vase } \\
\text { life/ } \\
\text { day }\end{array}$} & \multicolumn{2}{|c|}{ Anna } & \multicolumn{2}{|c|}{ Gold strike } \\
\hline & & Leaves & Petals & Leaves & Petals & & Leaves & Petals & Leaves & Petals \\
\hline \multirow{2}{*}{ Untreated } & 0 & 19.30 & 15.54 & 21.71 & 21.96 & 0 & 30.68 & 37.70 & 36.14 & 26.13 \\
\hline & 4 & 19.38 & 33.54 & 22.51 & 47.26 & 8 & 33.70 & 30.89 & 36.66 & 27.77 \\
\hline 1mM SA & & 20.16 & 19.26 & 24.14 & 21.73 & & 40.87 & 31.36 & 34.48 & 38.84 \\
\hline 6\% Eth & 4 & 20.22 & 17.92 & 22.06 & 25.31 & 8 & 41.18 & 36.82 & 42.12 & 57.56 \\
\hline $6 \%$ Eth + Suc $2 \%$ & & 22.85 & 27.38 & 23.69 & 39.03 & & 24.65 & 44.62 & 37.13 & 59.44 \\
\hline LSD $5 \%$ & & & 4.60 & & & & & 3.0 & & \\
\hline
\end{tabular}

$\mathrm{H}_{2} \mathrm{O}_{2}$, decreased in petals at $4^{\text {th }}$ day during vase life whereas the highest decrease $(17.92 \mathrm{nmol} / \mathrm{g}$ F.W) was observed with 6\% Eth for Anna cv. and $(21.73 \mathrm{nmol} / \mathrm{g} \mathrm{F.W})$ for Gold strike cv. with $1 \mathrm{mM}$ SA treatment when compared with control (33.54 and $47.26 \mathrm{nmol} / \mathrm{g}$ F.W) for Anna and Gold strike cvs. respectively. Singh et al. (2008) suggested that an increase in endogenous $\mathrm{H}_{2} \mathrm{O}_{2}$ levels and a decrease in anti-oxidant enzyme activities, may be partly responsible for initiating senescence in rose petals. In contrast, Rao et al. (1997) reported that treatment of leaves with $1 \mathrm{mM}$ SA for $8 \mathrm{hr}$., significantly enhanced $\mathrm{H}_{2} \mathrm{O}_{2}$ levels compared with leaves treated with water. Plants treated with SA have previously been shown to accumulate $\mathrm{H}_{2} \mathrm{O}_{2}$ (Chen et al., 1993; Fauth et al., 1996). However, these studies have provided detailed information concerning the pattern of $\mathrm{H}_{2} \mathrm{O}_{2}$ accumulation in plants treated with $\mathrm{SA} 1 \mathrm{mM}$. While, non-significance increased for $\mathrm{H}_{2} \mathrm{O}_{2}$ in leaves treatments compared with control at same day. Second produced from oxidative products was estimated. TBARS is usually used as an index of aging and physiological resistance. Researchers believe that treatments with extending compounds of the longevity can reduce physiological stress imposed on cut flowers and increase post-harvest life by reducing the accumulation of TBARS (Jin $\boldsymbol{e t}$ al., 2006). TBARS concentration has been observed where was recorded lowest of TBARS concentration in leaves for Anna and Gold strike cvs. in finally vase life ( $4^{\text {th }}$ and $8^{\text {th }}$ day) with SA $1 \mathrm{mM}$ and $6 \%$ Eth $+2 \%$ Suc. which recorded (24.65 and $34.48 \mathrm{nmol} / \mathrm{g} \mathrm{FW)} \mathrm{respectively}$ compared with control which recorded (33.70 and $36.66 \mathrm{nmol} / \mathrm{g} \mathrm{F} . \mathrm{W})$ during vase life for both Anna and Gold strike cvs., respectively. The results showed that, Anna cv. was positively affected by treatment compared to Gold strike cv. Similar with Zamani et al. (2011) showed that the use of salicylic acid and glutamine increased the vase life of cut rose flowers via decreasing the amount of TBARS. Confirmed by Kazemi et al. (2018) reported that the effect of $3 \mathrm{mM}$ SA treatment on MDA concentration increased significantly when compared to control. Additionally, Heidarnezhadian et al. (2017) they indicate that $1.5 \mathrm{mM} \mathrm{SA}$ with Gerbera cut flowers caused significant decrease TBARS concentration compared to control. In contrast, Mei-hua (2008) in Gerbera which showed that added SA decreased MDA level. Earlier studies by Panavas and Rubinstein (1998) and Fukuchi-Mizutani et al. (2000) showed that TBARS concentration has been related with an expansion in cell film penetrability and senescence in Daylily and Rose. It is important to mention that reduced lipid peroxidation and retained membrane stability have been demonstrated to be inversely proportional with flower senescence (Hatamzadeh et al., 2012). 
Our results coincide with Hossain et al. (2006) in Gladiolus flowers. Electrolyte leakage is often used as a parameter for determining tissue damage as the loss of membrane's selective permeability. Bartoli et al. (1995) loss of membrane integrity is the final and irreversible phase of senescence associated with membrane lipid peroxidation. In contrast, Paulin et al. (1986) found that lipid peroxidation (TBARS) increased after full bloom and the maximum increasing for TBARS was recorded in senescence stage. Lipid peroxidation and membrane stability were inversely proportional, and closely associated with flower senescence. Similar profiles had been observed in Chrysanthemum petal senescence by Bartoli $\boldsymbol{e t}$ al. (1995). Treated flowers with SA maintained a significantly lower level of lipid peroxidation at over vase life stages. Lipid peroxidation is mediated by reactive oxygen species (ROS) (Kellog, 1975).

\section{Effect of on Antioxidant Defiance Systems}

\section{Peroxidase POD activity}

The Peroxidase were reported to simultaneously decrease in Anna cultivar with all treated SA $1 \mathrm{mM}, 6 \%$ Eth and $6 \%$ Eth $+2 \%$ Suc compared with untreated cut flowers on leaves and petals, Table 6. SA $1 \mathrm{mM}, 6 \%$ Eth and $6 \%$ Eth $+2 \%$ Suc treated was recorded on leaves (64.94,
116.88 and $87.01 \%$ respectively) at $4^{\text {th }}$ in Anna cv. compared with untreated cut flowers (164.94\%). but recoded decreased (186.05, 162.79 and $146.51 \%$ for the three treatments respectively) on petals compared untreated cut flowers $(318.61 \%)$ in the same day. While, in Gold strike cv. was recorded (43.48, 84.68 and $99.28 \%$ for the three treatments respectively) on leaves compared with untreated cut flowers $(50.73 \%)$. Though, increase recorded on petals (154.80, 154.80 and $132.88 \%$, respectively) compared untreated cut flowers $(113.70 \%)$. The results indicated that treatment $\mathrm{SA} 1 \mathrm{mM}$ reduced the activity of POD, in all tissues in both cultivars compared with untreated cut flowers. The results agree with Kazemi et al. (2018) showed that SA treatment also resulted in high activity of both catalase and POD.

Also, similar with (Panavas and Rubinstein, 1998) reported that an increase in POD activity in petals may strengthen vascular cells, which remain functional during the later stage of senescence. Activity of POD was increased during senescence of Phalaenopsis cut flowers (Tewari et al., 2009). Plant cells presumably regulate $\mathrm{H}_{2} \mathrm{O}_{2}$ levels by coordinating activities of $\mathrm{H}_{2} \mathrm{O}_{2}^{-}$generating enzymes Such as SOD and $\mathrm{H}_{2} \mathrm{O}_{2}^{-}$degrading enzymes Such as POD (Creissen et al., 1994; Van Camp et al., 1994).

Table 6. Effect of best treatments (1mM SA, 6\% Eth and 6\% Eth $+2 \%$ Suc) on peroxidase (POD) and superoxide dismutase (SOD) enzyme activity in leaves and petals of cut 'Anna and Gold strike' Rose flowers

\begin{tabular}{|c|c|c|c|c|c|c|c|c|c|}
\hline \multirow[t]{3}{*}{ Cultivar } & \multicolumn{5}{|c|}{ POD } & \multicolumn{4}{|c|}{ SOD } \\
\hline & \multicolumn{3}{|c|}{ Anna } & \multicolumn{2}{|c|}{ Gold strike } & \multicolumn{2}{|c|}{ Anna } & \multicolumn{2}{|c|}{ Gold strike } \\
\hline & $\mathbf{0}$ & Leaves & Petals & Leaves & $\overline{\text { Petals }}$ & Leaves & Petals & Leaves & Petals \\
\hline Vase life/day & & 4 & 4 & 8 & 8 & 4 & 4 & 4 & 8 \\
\hline Untreated & 100 & 164.94 & 318.61 & 50.73 & 113.70 & 144.16 & 49.19 & 124.82 & 348.09 \\
\hline $1 \mathrm{mM} S A$ & 100 & 64.94 & 186.05 & 43.48 & 154.80 & 128.57 & 44.01 & 131.39 & 286.26 \\
\hline 6\% Eth & 100 & 116.88 & 162.79 & 84.78 & 154.80 & 157.79 & 50.49 & 159.85 & 245.04 \\
\hline $6 \%$ Eth + Suc $2 \%$ & 100 & 87.01 & 146.51 & 99.28 & 132.88 & 237.66 & 54.37 & 192.70 & 210.69 \\
\hline LSD $5 \%$ & & & 1.4 & & & & & .98 & \\
\hline
\end{tabular}




\section{Superoxide dismutase (SOD) activity}

The results indicated that the SA treated has reduced the activity of SOD, in more tissues in both cultivars compared with untreated cut flowers, Table 6. However, the highest SOD enzyme activity on leaves of Gold strike cv. which recorded $(131.39 \%, 159.85 \%$ and $192.70 \%$ ) for $1 \mathrm{mM} \mathrm{SA}, 6 \%$ Eth and 6\% Eth + $2 \%$ Suc respectively, compared with untreated cut flowers which recorded (124.82\%). Similar with Abri et al. (2013) maintained that on rose cut flowers showed that POD activity declined during flower vase life. Also, Ezhilmathi et al. (2007) showed that SOD activity declined during during senescence in carnation petals. On the other hand, SA is not believed to influence peroxidases enzyme (Hammond-Kosack and Jones, 1996). While, with Anna cv. was highest enzyme activity which recorded (157.79 and $237.66 \%$ ) with $6 \%$ Eth and $6 \%$ Eth $+2 \%$ Suc respectively in leaves compared with untreated cut flowers $(144.16 \%)$ in same day. These results indicated that POD is involved in the senescence of Rose flowers because it catalyzes the decomposition $\mathrm{H}_{2} \mathrm{O}_{2}^{-}$POD enzyme uses $\mathrm{H}_{2} \mathrm{O}_{2}$ as a substrate for several reactions and its specific activity increases in both rose cultivars. Earlier studies, $\mathrm{H}_{2} \mathrm{O}_{2}$ in plant cells is produced by the dismutation of $\mathrm{O}_{2}^{-}$by SOD localized in chloroplasts, cytosol, and mitochondria. Since the primary role of SOD is to generate $\mathrm{H}_{2} \mathrm{O}_{2}$ (Van Camp et al., 1994). $\mathrm{H}_{2} \mathrm{O}_{2}$ levels are related to the changes in SOD activity. Because SA enhanced $\mathrm{H}_{2} \mathrm{O}_{2}$ levels are closely related to increased SOD activities, we investigated whether SA mediated inactivation of $\mathrm{H}_{2} \mathrm{O}_{2}{ }^{-}$ degrading enzymes may have also contributed to elevated $\mathrm{H}_{2} \mathrm{O}_{2}$ levels in leaves treated with $\mathrm{SA}$ (Rao et al., 1997). Our observations that leaves treated with SA have enhanced SOD activities suggest increased production of $\mathrm{O}_{2}^{-}$in $\mathrm{SA}$ treated leaves. Similarly results indicate in gladiolus by Bartoli et al. (1995) and Daylily by Panavas and Rubinstein (1998) during senescence. To prevent the free radical propagation effect, the body uses antioxidants to stop the biochemical chain reaction. Antioxidants are compounds that dispose of reactive oxygen species by scavenging them, suppressing their formation, or opposing their actions (Cesari et al., 2004). Also, Kazemi et al. (2018) showed that preharvest and postharvest SA application prolonged the vase life of cut Roses through improving CAT and POD activity, and decreasing lipid peroxidation. Antioxidant mechanisms are complex and multifactorial. Antioxidants include the enzymes like GPX, SOD, and CAT different studies have shown that flower vase life is modulated by antioxidant (Baker et al., 1978). SA treated with Anthurium flowers maintained higher activities of CAT and SOD, compared to control flowers. SA is a well-known phenol that can prevent ACC-oxidase activity that is the direct precursor of ethylene and decrease ROS with increase enzyme antioxidant activity (Ansari and Misra, 2007; Mahdavian et al., 2007; Mba et al., 2007). The protective function of SA includes the regulation of ROS and antioxidant enzymes (Khan et al., 2003; Shi and Zhu, 2008). Similarly, Kazemi et al. (2011c) and Kazemi and Shokri (2011) showed that pretreatment with SA decreased the level of lipid peroxidation induced by paraquat oxidative stress in cut flowers. Also, the previous studies which showed that addition of 5-SSA in holding solution had positive effect on vase life and quality of cut flowers (Fariman and Tehranifar, 2011). The treatment with salicylic acid significantly extends the vase life, Kazemi et al. (2011a) and Kazemi et al. (2011 c) showed that the treatment of salicylic acid increase SOD activity. In general, Alteration in antioxidants activity Such as POD and SOD during postharvest life of cut flowers have been shown (Giannopolitis and Ries, 1997).

\section{Endogenous Hormones Concentration}

\section{GA3 concentration}

The level of GA3 showed a different instance between two Rose cultivars 'Anna and Gold strike' in the floral tissue during vase life after application $1 \mathrm{mM} \mathrm{SA}, 6 \%$ Eth and 6\% Eth $+2 \%$ Suc. In general, GA3 highest amount on Gold strike cv. compared Anna, in untreated and treated cut flowers. The highest amount of GA3 level was observed with $1 \mathrm{mM}$ SA which recorded (216.91 and $605.67 \mu \mathrm{g} / \mathrm{g}$ F.W $)$ at the finally vase life $4^{\text {th }}$ day for Anna cv. and $8^{\text {th }}$ day for Gold strike cv. respectively compared with untreated flowers (8.62 and $181.37 \mu \mathrm{g} / \mathrm{g} \mathrm{F.W})$ at 
the same days with both cultivars respectively, Table 7. Earlier studies, GA3 can inhibit many other processes, such as RNA and protein breakdown, that may be associated with senescence, GA3 may also delay senescence in petals and petioles (Rhodes, 1980). Also, the gibberellin is a general regulator of floral development (Pharis and King, 1985). In Arabidopsis, gibberellin promotes petals and stamens development (Cheng et al., 2004). GA3, an active form of gibberellins plays many roles in regulation of plant growth, flowering, cell division and elongation. GA3 promotes the flowering of Eustoma grandiflorum (Kawabata et al., 2009).

\section{CKs concentration}

The level of CKs showed a different instance between two Rose cultivars 'Anna and Gold strike' in the floral tissue during vase life after application 1mM SA, 6\% Eth and 6\% Eth ${ }_{+} 2 \%$ Suc, Table $7.1 \mathrm{mM}$ SA recorded the highest amount of CKs level $(26.01 \mu \mathrm{g} / \mathrm{g} \mathrm{F} . \mathrm{W})$ at $4^{\text {th }}$ day in Anna compared with their control $(0.60 \mu \mathrm{g} / \mathrm{g}$ F.W). But the best treatments in Gold strike cv. were $6 \%$ Eth $+2 \%$ Sucrose which recorded $(44.12 \mu \mathrm{g} / \mathrm{g}$ F.W $)$ at $8^{\text {th }}$ day as compared with the control $(2.83 \mu \mathrm{g} / \mathrm{g} \quad$ F.W $)$. The results confirmed by (Hunter et al., 2004; Tripathi and Tuteja, 2007) with Daffodil (Narcissus pseudonarcissus 'Dutch Master') they reported that Sucrose mediated increases in cytokinin's may be responsible for the delay of senescence of Daffodil (Narcissus pseudonarcissus 'Dutch Master'). Addionally, Mayak and Halevy, (1970) found that in leaves, there are some inverse correlations between endogenous cytokinin and senescence. For example, longer lived varieties of roses contain more cytokinin than short-lived varieties. Earlier studies, (Tavares and Kende, 1970) they reported that cytokinin maintained protein by retarding the rate of breakdown rather than enhancing the rate of synthesis. Van Staden and Dimalla, (1980) found that cytokinin levels are lower in detached flowers. Also, Thimann (1980) suggested that cytokinin's play an important role in controlling many of the processes that contribute to plant senescence. Additionally, Buchanan-Wollaston (1997) postulated that cytokinins, either directly or indirectly via a signaling pathway, inhibited the transcription of senescence associated genes.
About the action of cytokinin's it has been suggested that they act in synergy or in antagonism with other signals, leaves senescence is usually correlated with a decrease in cytokinin's in the leaves (Nooden et al., 1997).

\section{IAA concentration}

The level of IAA exhibited a different pattern between two Rose cultivars 'Anna and Gold strike' in the floral tissue during vase life after application salicylic acid at $1 \mathrm{mM}, 6 \%$ Eth and $6 \%$ Eth $+2 \%$ Suc, Table 7 . The highest amount of IAA level showed with SA at $1 \mathrm{mM}$ which recorded (60.02 and $268.10 \mu \mathrm{g} / \mathrm{g} \mathrm{F.w})$ at $4^{\text {th }}$ and $8^{\text {th }}$ day compared with control (27.42 and 40.70 $\mu \mathrm{g} / \mathrm{g}$ F.w) at the same days in both cultivars Anna and Gold strike respectively during their vase life. The results similar with (Ding et al., 1999). The level of indole acetic acid (IAA) increases during flower development in Coffea arabica (Schuch et al., 1994) and Polianthes tuberosa. IAA induced ethylene production knowledge of the regulation of ethylene biosynthesis during senescence of vegetative tissues is limited. Vegetative tissues usually produce very little ethylene. Typically, the rate of ethylene synthesis is primarily regulated by auxin (Imaseki et al., 1975). On the other hand, Jiang, et al. (2010) stated that an appropriate amount of IAA appears to be necessary for inflorescence differentiation, and a stable GA3 and ABA level for crown formation. These findings will do good to the manipulation of flowering process.

\section{ABA concentration}

The level of ABA proffered a different plate between two Rose cultivars 'Anna and Gold strike' in the floral tissue during vase life application 1mM SA, 6\% Eth and 6\% Eth $+2 \%$ Suc, Table 7. The $6 \%$ Eth $+2 \%$ Suc. treated which recorded the lowest amount of ABA level (14.30 and $14.58 \mu \mathrm{g} / \mathrm{g}$ F.W) and compared as control (20.44 and $14.46 \mu \mathrm{g} / \mathrm{g} \mathrm{F.W})$ in Anna $4^{\text {th }}$ day and $8^{\text {th }}$ day Gold strike cvs., respectively. Earlier studies, since ABA is known to accelerate petals senescence in ethyleneinsensitive flowers (Tripathi and Tuteja, 2007; Zhou et al., 2005; Panavas et al., 1998, Hunter et al., 2004) it appears that the Sucrose effects on flower senescence were also mediated at least 
Table 7. Effect of the best treatments (1mM SA, $6 \%$ Eth and $6 \%$ Eth $+2 \%$ Suc) on endogenous hormones (GA3, CKs, IAA and ABA) in floral tissues of cut 'Anna and Gold strike' Rose flowers

\begin{tabular}{|c|c|c|c|c|c|c|}
\hline \multirow[t]{2}{*}{ cvs. } & \multirow[t]{2}{*}{ Treatment } & \multirow{2}{*}{$\begin{array}{c}\text { Vase } \\
\text { life/days }\end{array}$} & \multicolumn{4}{|c|}{ Endogenous hormones ( $\mu \mathrm{g} / \mathrm{g}$ F.w) } \\
\hline & & & GA3 & CKs & IAA & $\overline{\mathbf{A B A}}$ \\
\hline \multirow{5}{*}{$\underset{\Xi}{Z}$} & \multirow{2}{*}{ Untreated } & 0 & 21.55 & 10.22 & 143.00 & 17.14 \\
\hline & & 4 & 8.62 & 0.60 & 27.42 & 20.44 \\
\hline & 1mM SA & & 216.91 & 26.01 & 60.02 & 17.05 \\
\hline & $6 \%$ Eth & 4 & 6.15 & 20.98 & 28.98 & 15.37 \\
\hline & $6 \%$ Eth $+2 \%$ Suc & & 118.36 & 19.07 & 52.51 & 14.30 \\
\hline \multirow{5}{*}{ 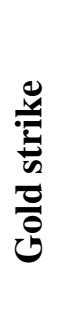 } & Untmo & 0 & 225.06 & 2.27 & 36.96 & 15.16 \\
\hline & & 8 & 181.37 & 2.83 & 40.70 & 14.46 \\
\hline & 1mM SA & \multirow{3}{*}{8} & 605.67 & 31.89 & 268.10 & 38.35 \\
\hline & $6 \%$ Eth & & 12.03 & 2.81 & 39.33 & 15.64 \\
\hline & $6 \%$ Eth $_{+} 2 \%$ Suc & & 131.70 & 44.12 & 55.70 & 14.58 \\
\hline \multicolumn{2}{|c|}{ LSD $5 \%$} & & 12.93 & 2.11 & 7.43 & 1.89 \\
\hline
\end{tabular}

in part by a reduction of $\mathrm{ABA}$ concentrations in outer tepals. In ethylene sensitive flowers, sugar supply delays petal senescence by modulating ethylene signaling pathway (Pun and Ichimura, 2003; Hoeberichts et al., 2007). Therefore, as it has already been described in the regulation of leaves senescence (Leon and Sheen, 2003; Wingler et al., 1998), it appears that there is a crosstalk between sugars and hormones in the regulation of tepal senescence both in ethylenesensitive and insensitive flowers. Addition, the effects of hormonal levels on inflorescence differentiation have not been explored, although it has been suggested that GA3 is required for flowering of a short-day Chrysanthemum plant (Sumitomo et al., 2009) the roles, if any, of $\mathrm{ABA}$ and cytokinin in floral transition and inflorescence differentiation and development have yet not to be defined. Moreover, higher ABA concentration were trend in short-lived cultivars compared to long-lived cultivars (Halevy and Mayak, 1975). ABA levels increase during the senescence of some flowers
(LePage-Degivry et al., 1991). Also, (Mayak and Halevy, 1972; Eze et al., 1986) which found that the ABA concentration of both rose and carnation petals was found to increase only late in the senescence process and was associated with large decreases in water potential.

This was in accordance with Wei et al. (2003) reported the $A B A$ is present in higher amounts in naturally senescing petals. Also, addition Hunter $\boldsymbol{e t}$ al. (2004) that $\mathrm{ABA}$ is a natural regulator of petal senescence in flowers. Previous reports by Arora et al. (2007) showed that ABA might be the possible cause and hormonal trigger of the accelerated senescence of ethylene insensitive gladiolus flowers. Additionally, Zhong and Ciafre (2011) showed that an exogenous application of ABA induced and advanced natural petal senescence resulting in the loss of membrane permeability, discoloration and in-rolling of cut Iris flowers, and suggested a direct role of $\mathrm{ABA}$ in upregulation of early steps of ethyleneindependent petal senescence. 


\section{Conclusion}

It can be concluded that a significant improvement in vase life cut of Rosa hybrida L. cultivars 'Anna and Gold strike' Rose flowers was occurred when treated with showed the maximum flowers longevity (7 and 12 days) with $6 \%$ Eth $+2 \%$ Suc and $1 \mathrm{mM}$ SA compared as untreated flower (4 and 8 days) in Anna and Gold strike cvs., respectively. Also, 6\% Eth $+2 \%$ Suc and SA at $1 \mathrm{mM}$ showed the better for water relations (water uptake, water loss and relative fresh weight), photosynthetic pigments concentration, membrane stability as well also less oxidative products as $\mathrm{H}_{2} \mathrm{O}_{2}$ and have appearing of defense system by antioxidant enzymes as POD and SOD activity in more treatments. Furthermore, the levels of CKS, IAA and GA3 were increased in treated plants, while, $\mathrm{ABA}$ decreased in both cut 'Anna and Gold strike' rose flowers compared untreated. In general, the results suggest that SA and combination of Eth + Suc increases vase life by improving the antioxidant enzymes system, endogenous growth hormones during rose flower senescence. Also, Gold strike cv. was move responsive than Anna cv. to proposed transactions. On the other hand, the lowest coefficients were STS, 5-SSA and BA treatments.

\section{REFERENCES}

Abdolmaleki, M., M. Khosh-Khui, S. Eshghi and A. Ramezanian (2015). Improvement in vase life of cut Rose cv. "Dolce Vita" by preharvest foliar application of calcium chloride and salicylic acid. Int. J. Hort. Sci. Technol., 2 : 55-66.

Abri, F., M. Ghasemnezhad, R. Hasansajedi and D. Bakhshi (2013). Effect of ascorbic acid on vase life and petal senescence in cut Rose flowers (Rosa hybrida) cv. 'Royal Class'. Ame.-Eurasian J. Agric. and Environ. Sci., 13: 38-43.

Ansari, M.S. and N. Misra (2007). Miraculous role of salicylic acid in plant and animal system. Ame. J. Pl. Physiol., 2:51-58.

Arora, A.V.P., S.S. Singh, D.N. Sindhu and S.R. Voleti (2007). Oxidative stress mechanisms during flower senescence. Plant Stress Global Science Books, Japan, 228.

Asgari, M. and Moghadam, A.L. (2015). Comparison of different salicylic acid application ways as a preservative on postharvest life of Gerbera cut flowers. Agricultural Communications, 3 (4): 1-8.

Baker, J.E., M. Lieberman and J.D. Anderson (1978). Inhibition of ethylene production in fruit slices by Rhizobitoxine analogs and free radical scavengers. Pl. Physiol., 61: 886-888.

Bartoli, C.G., M. Simomtacchi, J.J. Guiamet, E. Montaldi and S. Puntarulo (1995). Antioxidant enzymes and lipid peroxidation during aging of Chrysanthemum morifolium petals. Pl. Sci., 104 :161-168.

Bayat, H. and M.H. Aminifard (2017). Salicylic acid treatment extends the vase life of five commercial cut flowers. Electronic J. Biol., 13 (1): 67-72.

Beyer, W.F. and I. Fridovich (1987). Assaying for superoxide dismutase activity: some large consequences of minor changes in condition. Anal. Bioch., 161 :559-566.

Buchanan-Wollaston, V. (1997). The molecular biology of leaves senescence. J. Exp. Bot., 48: 181-199.

Butt, S.J. (2003). A review on prolonging the vase life of Roses. p: 49-53. Pakistan Rose Annual. Published by Pak. Nat. Rose Soc.

Capdeville, G., L.A. Maffia, F.L. Finger and U.G. Batista (2003). Gray mold severity and vase life of Rose buds after pulsing with citric acid, salicylic acid, calcium sulfate, sucrose and silver thiosulfate. Fitopatol Brasilia, 28: 289-294.

Cesari, M., M. Pahor, B. Bartali, A. Cherubini, B.W. Penninx, G.R. Williams, H. Atkinson, A. Martin, J.M. Guralnik and L. Ferrucci (2004). Antioxidants and physical performance in elderly persons: The invecchiare in Chianti (Inchianti) study. Ame. J. Clin. Nutr., 79: 289-294.

Chance, B. and C. Maehly (1955). Assay of catalase and peroxidases. Methods in Enzymol., 2 (11): 764-775. 
Chen, Y.P. and W.Y. Yang (2005). Determination of GA3, IAA, ABA and ZT in dormant buds of a Llium ovalifolium by HPLC. J. Sichuan Agric. Univ., 23 :498-500.

Chen, Z., J.R. Ricigliano and D.F. Klessig (1993). Purification and characterization of a soluble salicylic acid binding protein from tobacco. Proc. Nat. Acad. Sci., USA, 90: 9533-9537.

Cheng, H., L. Qin, S. Lee, X. Fu, D.E. Richards, D. Cao, D. Luo, N.P. Harberd and J. Peng (2004). Gibberellin regulates Arabidopsis floral development via suppression of DELLA protein function. Dev., $131: 1055-$ 1064.

Cho, M.S., F.G. Celikel, L. Dodge and M.S. Reid (2001). Sucrose enhances the postharvest quality of cut flowers of Eustoma grandiflorum (Raf.) Shinn. Acta Hort., 543: 305-315.

Costat, (1990). Costata reference manual (Version 2.1) Copyright Coltort Software. P.O. Box. 1149, Berkery, CA, 94701. USA.

Creissen, G.P., E.A. Edwards and P.M. Mullineaux (1994). Glutathione reductase and ascorbate peroxidase. In CH Foyer, PM Mullineaux, eds, causes of photooxidative stress and amelioration of defense systems in plants. CRC Press, Boca Raton, FL, 343-364.

Dhindsa, R.S., D. Plumb-Dhindsa and T. Thorpe (1981). Leaves senescence correlated with increased levels of peroxidation and decreased levels of superoxide dismutase and catalase. J. Exp. Bot., 32 : 93-101.

Ding, S.F., W.S. Chen, C.L. Sul, B.S. Du, B. Twitchin and V.K. Bhaskar (1999). Changes in free and conjugated indole-3-acetic acid during early stage of flower bud differentiation in Polianthes tuberosa. Pl. Physiol. and Bioch., 37: 161-165.

Doi, M. and M.S. Reid (1995). Sucrose improves the postharvest life of cut flowers of a hybrid Limonium. Hortiscience, 30: 1058-1060.

El-Nabarawy, M.A., S.H. El-Kafafi, H.E. Abo El-Enien and M.K. Salama (2018). Senescence flowers of roses:1-comparison between Anna and Gold strike cvs. Int. Conf., Fac. Agric. J., Al-Azhar Univ., 22-27.
El-Quesni, F.E.M., N.G. Abd El-Aziz and M.M. Kandil (2009). Some studies on the effect of ascorbic acid and $\alpha$-tocopherol on the growth and some chemical composition of Hibiscus rosa sinensis L. at Nubaria ozean. J. Appl. Sci., 2 (2) :159-167.

Eze, J.M.O., S. Mayak, J.E. Thompson and E.B. Dumbroff (1986). Senescence in cut carnation flowers: temporal and physiological relationships among water status, ethylene, abscisic acid and membrane permeability. Pl. Physiol., 68 : 323-328.

Ezhilmathi, K., V.P. Singh, A. Arora and R.K. Sairam (2007). Effect of 5-sulfosalicylic acid on antioxidant activity in relation to vase life of Gladiolus cut flowers. Plant Growth Regulation, 51 :99-108.

Fan, M.H., J.X. Wang, G. Shi, L.N. Shi and R.F. Li (2008). Salicylic acid and BA effects in shelf-life improvement of Gerbera jasmoesonii cut flowers. Anhui Agric. Sci. Bulletin. http://en.cnki. com.cn/ Article_e n/CJFDTOTAL-BFYY200808060.htm.

Fariman, Z.K. and A. Tehranifar (2011). Effect of essential oils, ethanol and methanol to extend the vase-life of carnation (Dianthus caryophyllus L.) flowers. Biol. and Env. Sci., 5 : 91-94.

Farrokhzad, A., A. Khalighi, Y. Mostofi and R. Naderi (2005). Role of ethanol in the vase life and ethylene production in cut lisianthus (Eustoma grandiflorum Mariachii. cv. Blue) flowers. J. Agric. and Soc. Sci., 1 : 309-312.

Fauth, M., A. Merten, M.G. Hahn, W. Jeblick and H. Kauss (1996). Competence for elicitation of hydrogen peroxide in hypocotyls of Cucumber is induced by breaching the cuticle and is enhanced by salicylic acid. Pl. Physiol., 110: 347-354.

Ferrante, A., A. Mensuali-Sodi and G. Serra (2009). Effect of thidiazuron and gibberellic acid on leaves yellowing of cut stock flowers. Cent. Europ. J. Biol., 4 : 461-468.

Fukuchi-Mizutani, M., K. Ishiguro, T. Nakayuama, Y. Utsunomia, Y. Tanaka, T. Kusumi and T. Ueda (2000). Molecular and functional characterization of a Rose 
lipoxygenase cDNA related to flower senescence. Pl. Sci., 160 : 129-137.

Giannopolitis,C. and Ries, S. (1997). Superoxid dismutase.I: Occurence in higher plant. Pl. Physiol., 59: 309-314.

Guiboileau, A., R. Sormani, C. Meyer and C. Masclaux-Daubresse (2010). Senescence and death of plant organs: Nutrient recycling and developmental regulation. Biol. Reports, 333: 382-391.

Halevy, A.H. and S. Mayak (1975). Interrelationship of several phytohormones in the regulation of rose petal senescence. Acta Hort., 41:103-116.

Halevy, A.H. and S. Mayak (1981). Senescence and postharvest physiology of cut flowers: part 2. Hort. Rev., 3 :59-153.

Hamidi-Imani, M., Hashemabadi, D., Kaviani, B. and Zarchini, M. (2013). Improving water relations and postharvest quality of cut Rose (Rosa hybrida L. cv. 'Avalanche') by ethanol. Ann. Biol. Res., 4 : 256-259.

Hammond-Kossack, K.E. and J.D.G. Jones (1996). Resistance gene dependent plant defense responses. Plant Cell, 8: 1773-1807.

Han, S.S. (2001). Benzyladenine and gibberellins improve post-harvest quality of cut Asiatic and oriental lilies. Hort. Sci., 36 :741-745.

Han, S.S. (2003). Role of sugar in the vase solution on postharvest flower and leaves quality of oriental lily stargazer. Hort. Sci., $38: 412-416$.

Hassanein, R.A., H.A. Hashem and R.R. Khalil (2012). Stigmasterol treatment increases salt stress tolerance of Faba Bean plants by enhancing antioxidant systems. Pl. Econ. J., 5: 476-485.

Hajizadeh, H.S., A. Farokhzad and G.H. Chelan (2012). Using of preservative solutions to improve postharvest life of Rosa Hybrid cv. Black magic. J. Agric. Technol., 8 (5): 18011810.

Hatamzadeh, A., M. Hatami and M. Ghasemnezhad (2012). Efficiency of salicylic acid delay petal senescence and extended quality of cut spikes of Gladiolus grandiflora cv 'Wing's Sensation'. Afr. J. Agric. Res., 7: 540-545.

Heidarnezhadian, H., B. Eghbali and M. Kazemi (2017). Postharvest life of cut Gerbera flowers as affected by salicylic acid and citric acid. Trakia J. Sci., 1: 27-29.

Heins, R.D. (1980). Inhibition of ethylene synthesis and senescence in carnation by ethanol. J. Ame. Soc. Hort. Sci., 105 : 141144.

Hoeberichts, F., W. van Doorn, O. Hall and M. van Wordragen (2007). Sucrose prevents upregulation of senescence-associated genes in carnation petals. J. Exp. Bot., 58: 2873-2885.

Hossain, Z., A.K. Mandal, S.K. Datta and A.M. Biswas (2006). Decline in ascorbate peroxidase activity a prerequisite factor for tepal senescence in Gladiolus. Pl. Physiol., $163: 186-194$.

Hunter, D., A. Ferrante, P. Vernieri and M. Reid (2004). Role of abscisic acid in perianth senescence of daffodil (Narcissus pseudonarcissus 'Dutch Master'), Pl. Physiol., $121: 313-332$.

Imaseki, H., K. Kondo and A. Watanabe (1975). Mechanism of cytokinin action on auxininduced ethylene production. Pl. Cell Physiol., 16: 777-787.

Irving, D.E. and D.C. Joyce (1995). Sucrose supply can increase longevity of broccoli (Brassica oleracea) branchlets kept at $22^{\circ} \mathrm{C}$. Pl. Growth Reg., 17 :251-256.

Jaleel, C.A., P. Manivannan, B. Sankar, A. Kishorekumar, R. Gopi, R. Somasundaram and R. Panneerselvam (2007). Induction of drought stress tolerance by ketoconazole in Catharanthus Roseus is mediated by enhanced antioxidant potentials and secondary metabolite accumulation. Colloids Surfaces B: Biointerfaces, 60: 201-206.

Jamali, B. and M. Rahemi (2011). Carnation flowers senescence as influenced by nickel, cobalt and silicon. J. Biol. and Environ. Sci., $5: 147-152$.

Je-drzejuk, A., J. Rabiza-Swider, E. Skutnik and A. Łukaszewska (2016). Some factors 
affecting longevity of cut lilacs. Postharvest Biol. and Technol., 111 : 247-255.

Jiang, S.M., H.B. Chen, M.S.M. Zhang, F.D. Chen and W.M. Fang (2010). Changes of endogenous hormone levels during short-day inductive floral initiation and inflorescence differentiation of Chrysanthemum grandiflorum 'Jingyun' B.B. Int. J. Pl. Prod., 4: 1735-6814.

Jin, J., S.H. Ningwei, M. Nan, B. Jinhe and C. Junping (2006). Regulation of ascorbate peroxidase at the transcript level is involved in tolerance to postharvest water deficit stress in the cut rose Samantha. J. Postharvest Biol. and Technol., 40: 236-243.

Kaltaler, R.E.L. and P.L. Steponkus (1976). Factors affecting respiration in cut Roses. J. Ame. Soc. Hort. Sci., 101 : 352-354.

Kawabata, S., Y. Li, T. Saito and B. Zhou (2009). Identification of differentially expressed genes during flower opening by suppression subtractive hybridization and cDNA microarray analysis in Eustoma grandiflorum. Sci. Hort., 122: 129-133.

Kazemi, M. and A. Ameri (2012). Response of vase-life carnation cut flower to salicylic acid, silver nanoparticles, glutamine and essential oil. Asian J. Anim. Sci., 6 (3): 122131.

Kazemi, M., M. Aran and S. Zamani (2011a). Effect of some treatment chemicals on keeping quality and vase-life of cut flowers. Ame. J. Pl. Physiol., 6: 99-105.

Kazemi, M., M. Aran and S. Zamani (2011b). Interaction between glutamine and different chemicals on extending the vase life of cut flowers of 'Prato' lily. Ame. J. Pl. Physiol., 6: 120-125.

Kazemi, M., M. Aran and S. Zamani (2011c). Extending the vase life of Lisianthus (Eustoma grandiflorum Mariachii. cv. blue) with different preservatives. Ame. J. Pl. Physiol., 6 :167-175.

Kazemi, M., V. Abdossia, S.K. Jaria and A.R.L. Moghadamb (2018). Effect of pre- and postharvest salicylic acid treatment on physio-chemical attributes in relation to the vase life of cut Rose flowers. J. Hort. Sci. and Biotechnol., 93(1): 81-90.

Kazemi, M. and V. Shokri (2011). Role of salicylic acid in decreases of membrane senescence in cut Lisianthus flowers. World Appl. Sci. J., 13:142-146.

Kellog, D.E. (1975). The role of phyletic change in the evolution of pseudocubus vema. (Radiolaria). Paleobiol., 1: 359-370.

Khan, W., B. Prithiviraj and D.L. Smith (2003). Photosynthetic response of corn and soybean to foliar application of salicylates. Pl. Physiol., 160 :485-492.

Kiaseh, D.Y. and M. Yadegari (2016). The effect of ethanol and cycloheximide on the vase life of cut flowers Alstroemeria (Alstroemeria hybrida). J. Ornamental Pl., 6: 73-82.

LePage-Degivry, M.T., M. Orlandini, G. Garello, P. Barthe and S. Gudin (1991). Regulation of ABA levels in senescing petals of rose flowers. J. Plant Growth Regul., 10 : 67-72.

Leon, P. and J. Sheen (2003). Sugar and hormone connections. Trends Pl. Sci., 8 : 110-116.

Liao, L.J., Y. Lin, K. Huang, W. Chen, Y. Cheng, Y.H. Lin, K.L. Huang, W.S. Chen, and Y.M. Cheng (2000). Postharvest life of cut Rose flowers as affected by silver thiosulfate and Sucrose. Botanical Bulletin of Acad. Sinica, 4: 299-303.

Lu, P., J. Cao, S. He, J. Liu, H. Li, G. Cheng, Y. Ding and D.C. Joyce (2010). Nano-silver pulse treatments improve water relations of cut rose cv. 'Movie' Star flowers. Postharvest Biol. and Technol., 57:196-202.

Lichtenthaler, H.K. and A.R. Wellburn (1985). Determination of total carotenoids and chlorophylls $\mathrm{a}$ and $\mathrm{b}$ of leaves in different solvents. Bioch. Soc. Transactions, 11: 591592.

Mahdavian, K., K.M. Kalantari and M. Ghorbanli (2007). The effect of different concentrations of salicylic acid on protective enzyme activities of pepper (Capsicum 
annuum L.) plants. Pak. J. Biol. Sci., 10: 3162-3165.

Marina, R. and P. Javier (2011). Salicylic acid beyond defense its role in plant growth and development. J. Exp. Bot., 62 : 3321-3338.

Mayak, S. and A.H. Halevy (1970) Cytokinin activity in rose petals and its relation to senescence. Pl. Physiol., 46: 497-499.

Mayak, S. and A.H. Halevy (1972). Interrelationships of ethylene and abscisic acid in the control of rose petal senescence. Pl. Physiol., 50 :341-346

Mayak, S. and A.M. Kofranek (1976). Altering the sensitivity of carnation flowers (Dianthus caryophyllug L.) to ethylene. J. Ame. Soc. Hort. Sci., 101: 503-506.

Mayak, S. and T. Triosh (1993). Unusual ethylene related behavior in senescing flowers of the Carnation sandrosa. Physiol. Plantarum, 88: 420-426.

Mba, F.O., X. Zhi-Ting and Q. Hai-Jie (2007). Salicylic acid alleviates the cadmium toxicity in chinese cabbages (Brassica chinensis). Pak. J. Biol. Sci., 10 :3065-3071.

Mehraj, H., I.H. Shiam, T. Taufique, M. Shamsuzzoha and A.F.M.J. Uddin (2016). Effects of floral preservative solutions for vase life evaluation of gerbera. J. Biosc. and Agric. Res., 9 :804-811.

Mei-hua, F., W. Jian-xin, L. Shi, G. Shi and L. Fan (2008). Salicylic acid and 6-ba effects in shelf-life improvement of Gerbera jamesonii cut flowers. Anhui Agric. Sci. Bulletin.

Mori, I.C., R. Pinontoan, T. Kawano and S. Muto (2001). Involvement of superoxide generation in salicylic acid -induced stomatal closure in Vicia faba. Plant Cell Physiol., 42: 383-1388.

Nematollah-Sani, R., R. Kazemi, H. Dogolsar and S. Nozari (2010). First Proc. Natl. Sym. Agriculture Sustainable Dev., 1-4.

Nooden, L.D., J.J. Guiamet and I. John (1997). Senescence mechanisms. Pl. Physiol., 101: 746-753.

Ohkawa, H., N. Ohishi and K. Yagi (1979). Assay for lipid peroxides in animal tissues by thiobarbituric acid reaction. Anal. Bioch., 95 : 351-358.

Panavas, T. and B. Rubinstein (1998). Oxidative events during programmed cell death of daylily (Hemerocallis hybrid) petals. Plant Sci., 133 :125-138.

Panavas, T., E.L. Walker and B. Rubinstein (1998). Possible involvement of abscisic acid in senescence of daylily petals. J. Exp. Bot., $49: 1987-1997$.

Paulin, A., M.J. Droillard and J.M. Bureau (1986). Effect of a free radical scavenger, 3,4,5- trichlorophenol, on ethylene prodaction and on changes in lipids and membrane integrity during senescence of petals of cut carnations (Dianthuse caryophyllus). Physiol. Plantarum, 67 : 465471.

Pharis, R.P. and R.W. King (1985). Gibberellins and reproductive development in seed plants. Annul. Rev. Pl. Physiol., 36 : 517 -568.

Ping L.X., P.X. Qun, Z.Z. Qi and L.Z. Liang (2004). Preservation effects of salicylic acid on cut Roses. Hort. Dept., South China Agric. Univ., Guangzhou 510642, Guangdong, China.

Podd, L.A. and J.V. Staden (2004). The role of ethanol and acetaldehyde in flower senescence and fruit ripening. J. Pl. Growth Regulators, 26: 183-189.

Pun, U.K. and K. Ichimura (2003). Role of sugars in senescence and biosynthesis of ethylene in cut flowers. Japanese Agric. Res. Quality, 37 : 219-224.

Pun, U.K., R.N. Rowe, J.H. Rowarth, M.F. Barnes, C. Dawson and J.A. Oheyes (1999). Influence of ethanol on climacteric senescence in five cultivars of carnation. N.Z. Crop Hort. Sci., 27: 69-77.

Rahmani, I., N. Ahmadi, F. Ghanati and M. Sadeghi (2015). Effects of salicylic acid applied pre- or post-transport on post-harvest characteristics and antioxidant enzyme activity of gladiolus cut flower spikes. New Zealand J. Crop and Hort. Sci., 43 (4): 294305.

Rao, M.V., G. Paliyath, D.P. Ormrod, D.P. Murr and C.B. Watkins (1997). Influence of 
salicylic acid on $\mathrm{H}_{2} \mathrm{O}_{2}$ production, oxidative stress, and $\mathrm{H}_{2} \mathrm{O}_{2}$-metabolizing enzymes' salicylic acid-mediated oxidative damage requires $\mathrm{H}_{2} \mathrm{O}_{2}$. Pl. Physiol., 115 :137-1 49.

Rao, S.R., A. Qayyum, A. Razzaq, M. Ahmad, I. Mahmood and A. Sher (2012). Role of foliar application of salicylic acid and tryptophan in drought tolerance of maize. J. Anim. and Pl. Sci., 22 :768-772.

Raskin, I. (1992). Role of salicylic acid in plants. Ann. Rev. Pl. Physiol. and Pl. Molec. Biol., 43:439-463.

Rhodes, M.J.C. (1980). The maturation and ripening of fruits. In Senescence in Plants (K.V. Thimann, Ed.), CRC Press, Boca Raton, Florida., 157-205.

Sairam, R.K. and A. Tyagi (2004). Physiology and molecular biology of salinity stress tolerance in plants. Current Sci. J., 86: 407-421.

Schuch, U.K., A.N. Azarenko and L.H. Fuchigami (1994). Endogenous IAA levels and development of coffee flower buds from dormancy to anthesis. Pl. Growth Reg., 15: 33-41.

Serrano, M., F. Romojaro, J.L. Casas and M. Acosta (1991). Ethylene and polyamine metabolism in climacteric and nonclimacteric carnation flowers. Hort. Sci., 26: 894-896.

Seyf, M., A. Khalighi, Y. Mostofi and R. Naderi (2012). Study on the effect of aluminum sulfate treatment on postharvest life of the cut rose 'Boeing' (Rosa hybrid cv. Boeing). J. Hort. and Biotechnol., 16 (3) :128-132.

Sharif-Hossain, A.B.M., A.N. Boyce, H.M.A. Majid, S. Chandran and R. Zuliana (2007). Effect of ethanol on the longevity and abscission of Bougainvillea flower. J. Sci. and Technol., $1: 184-193$.

Shi, Q. and Z. Zhu (2008). Effects of exogenous salicylic acid on manganese toxicity, element contents and antioxidative system in cucumber. Env. Exp. Bot., 63: 317-326.

Singh, A. and A.K. Tiwari (2002). Effect of pulsing on postharvest life of Rose cv. doris and tystermann. South Indian Hort., 50 :140144.
Singh, A., J. Kumar and P. Singh (2008). Effect of plant growth regulators and sucrose on postharvest physiology, membrane stability and vase life of cut spikes of gladiolus. Pl. Growth Reg., 55 : 221-229.

Soleimany-Fard, E., K. Hemmati and A. Khalighi (2013). Improving the keeping quality and vase life of cut alstroemeria flowers by pre and post-harvest salicylic acid treatments. Notulae Scientia Biologicae, 5 (3) : 364-370.

Sumitomo, K., T. Li and T. Hisamatsu (2009). Gibberellin promotes flowering of chrysanthemum by upregulating CMFL, a Chrysanthemum Floricaula/Leavesy homologous gene. Pl. Sci., 176: 643-649.

Tang, T., X. Wen and C. Lu (2005). Differential changes in degradation of chlorophyllprotein complexes of photosystem I and photosystem II during flag leaves senescence of rice. Pl. Physiol. and Biotechnol., 43 :193201.

Tavares, J. and H. Kende (1970). The effect of 6-benzylaminopurine on protein metabolism in senescing corn leaves. Phytochem., 9: 1763-1770.

Tewari, R.K., P. Kumar, S. Kim, H. Eun-Joo and K. Paek (2009). Nitric oxide retards xanthine oxidase-mediated superoxide anion generation in Phalaenopsis flower: an implication of $\mathrm{NO}$ in the senescence and oxidative stress regulation. Pl. Cell Reports, 28: 267-279.

Thimann, K.V. (1980). The senescence of leaves. In "Senescence in Plants" (Thimann, K. V. ed.), 85-115. CRC Press, Boca Raton, Florida.

Tripathi, S. and N. Tuteja, (2007). Integrated signaling in flower senescence: an overview, Plant Signal Behavior, 2 :437- 445.

Umbese, C.E., C.K. Oji and T.S. Osinaike (2010). Phenological and physiological changes induced by extending vase life of cut flowers of Allamanda cathartica $L$. var. grandiflora. J. Sci. Res. and Adv., 12: 1-9.

Vahdati, N.M., A. Tehranifar, H. Bayat and Y. Selahvarzi (2012). Salicylic and citric acid 
treatments improve the vase life of cut chrysanthemum flowers. J. Agric. Sci. Technol., 14:879-887.

Van Camp, W., M. Van Montagu and D. Inze (1994). Superoxide dismutase. In CH Foyer, PM Mullineaux, eds, causes of photooxidative stress and amelioration of defense systems in plants. CRC Press, Boca Raton, FL, 318-341.

Van Doorn, W.G. (1997). Water relations of cut flowers. Hort. Rev., 18: 1-85.

Van Staden J. and G.G. Dimalla (1980). The effect of silver thiosulphate preservative on the physiology of cut carnations. II. Influence on endogenous cytokinin. Pl. Physiol., 99: 19-26.

Velikova, V., I. Yordanov and A. Edreva (2000). Oxidative stress and some antioxidant systems in acid rain-treated bean plants: protective roles of exogenous polyamines. Pl. Sci., 151: 59-66.

Wei, H.C., J. Sanny, H. Shu, D.L. Baillie, J.A. Brill, J.V. Price and N. Harden (2003). The Sac1 lipid phosphatase regulates cell shape change and the JNK cascade during dorsal closure in Drosophila. Current Biol., 13 : 1882-1887.

Wingler, A., von A. Schaewen, R.P. Leegood, W. Lea and P. Quick (1998). Regulation of leaves senescence by cytokinin, sugars, and light. Effects on NADH-dependent hydroxy pyruvate reductase, Pl. Physiol., 116 : 329335.

Wu, M.J., Z. Lorenzo, M.E. Saltveit and M.S. Reid (1992). Alcohols and carnation senescence. Hort. Sci., 27: 136-138.

Yamane, K., T. Kawauchi, Y.T. Yamaki and N. Fujishige (2005). Effects of treatment with trehalose and Sucrose on sugar contents, ion leakage and senescence of florets in cut gladiolus spikes. Acta Hort., 669 :301-308.

Yusuf, M., S.A. Hasan, B. Ali, S. Hayat, Q. Fariduddin and A. Ahmad (2007). Effect of salicylic acid on salinity induced changes in Brassica juncea. J. Integrity of Pl. Biol., 50 : 1096-1102.

Zamani, S., M. Kazemi and M. Aran (2011). Postharvest life of cut rose flowers as affected by salicylic acid and glutamine. World Appl. Sci. J., 12 :1621-1624.

Zhong, Y. and C. Ciafre (2011). Role of ABA in ethylene-independent Iris flower senescence. In: Int. Conf. Food Eng. and Biotechnol., 9, Singapore.

Zhou, Y., C. Wang, H. Ge, F. Hoeberichts and P. Visser (2005). Programmed cell death in relation to petal senescence in ornamental plants, Acta Bot. Singapore, 47: 641- 650. 


\section{شيخوخة أزهار الورد بـ ـ تنظيم شيخوختها وإطالة فترة بقاء ها

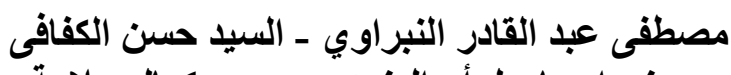

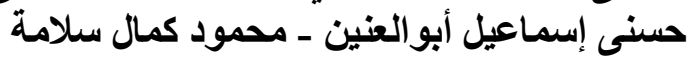

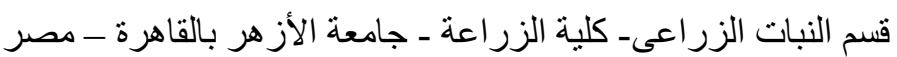

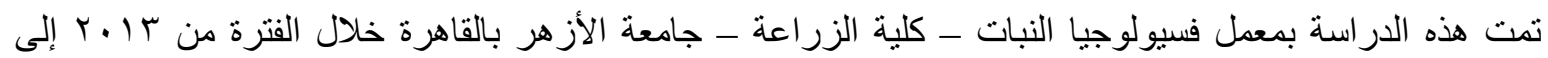

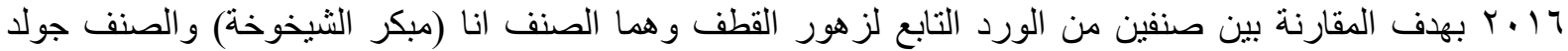

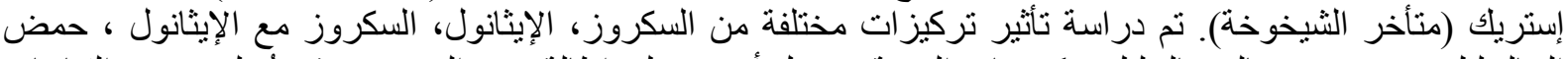

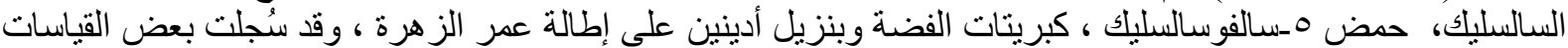

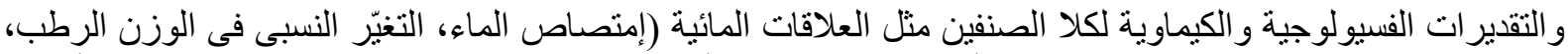

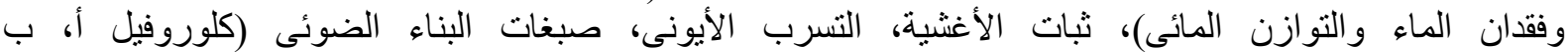

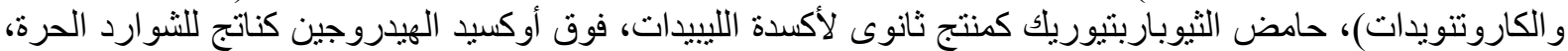

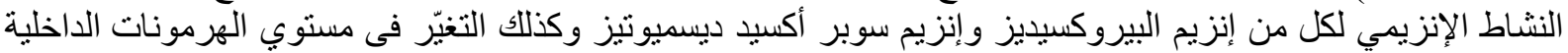

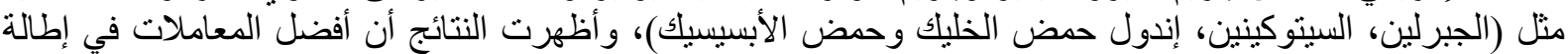

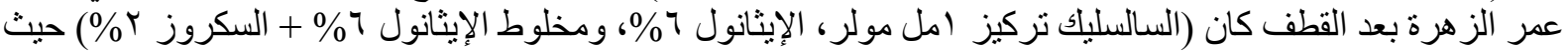

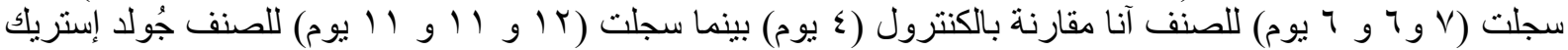

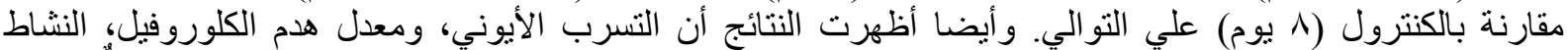

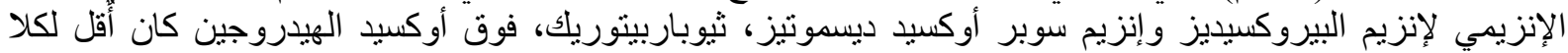

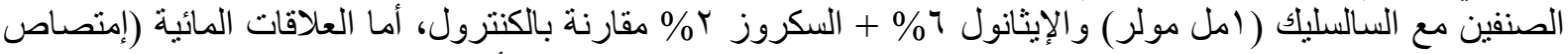

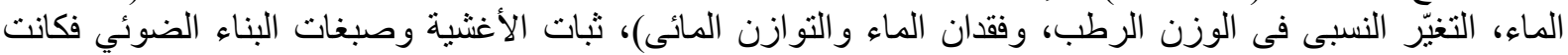

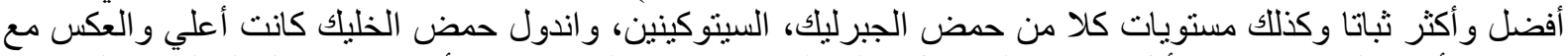

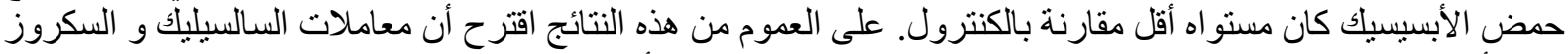

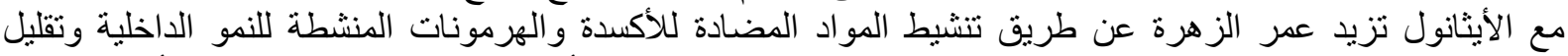

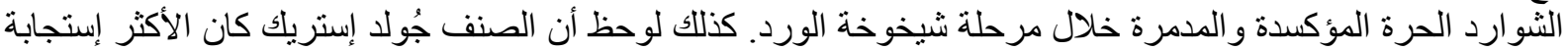

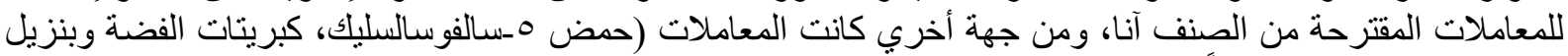
أدينين) أقل المعاملات تأثنير اً.

أستاذ فسيولوجيا النبات ـ كلية الزر اعة - جامعة عين شمس. أستاذ فسيولوجيا النبات المتفرغ غليات كلية الزر اعة - جامعة الزقازيق. 